\title{
SYNTHESIS OF NEUTRAL LIPIDS IN CHLORELLA SP. UNDER DIFFERENT LIGHT AND CARBONATE CONDITIONS
}

\author{
Jazmín-Vanessa Pérez-Pazos $^{1}$ and Pablo Fernández-Izquierdo ${ }^{1 *}$ \\ 'Microbial Biotechnology Research Group, Universidad de Nariño, Pasto, Nariño, Colombia \\ e-mail: pabfdez@gmail.com
}

(Received Jul. 08, 2011 ; Accepted Nov. 11, 2011)

\begin{abstract}
$\mathrm{L}$ ipids are biomolecules of great scientific and biotechnological interest due to their extensive applications. Microalgae are potential biological systems used in the synthesis of lipids, particularly Chlorella sp., which is characterized by its high lipid content and for having the right profile for the obtainment of biofuel. Lipid production in microalgae is influenced by several physical and chemical factors. Any modification thereof can cause a stress response represented by changes in synthesized lipid composition, varying from one species to another. This paper evaluates the effect of different light wavelengths, photoperiods and calcium carbonate $\left(\mathrm{CaCO}_{3}\right)$ supply in lipid synthesis in Chlorella sp. In order to do so, the microalgae was grown in Bold's Basal Medium (BBM) at $20^{\circ} \mathrm{C}$ with constant aeration and subject to low blue $(470 \mathrm{~nm})$ and red $(700 \mathrm{~nm})$ light wavelengths, $0,5 \mathrm{~g} \cdot \mathrm{L}^{-1}$ and $1,5 \mathrm{~g} \cdot \mathrm{L}^{-1}$ concentrations of $\mathrm{CaCO}_{3}$ and 6-hour light, 18-hour darkness (6:18) and 18-hour light, 6-hour darkness (18:6) photoperiods. The results indicate a higher growth rate for microalgae under red light, $0,5 \mathrm{~g} \cdot \mathrm{L}^{-1}$ of $\mathrm{CaCO}_{3}$ and a photoperiod of 6:18. On the other hand, lipid production is higher under blue light, 1,5 g. $\mathrm{L}^{-1}$ of $\mathrm{CaCO}_{3}$ and an 18:6 photoperiod. Analysis by gas chromatography indicate that the fatty acids in the samples are oleic, linoleic and palmitoleic, which are of recognized importance in the biodiesel industry. This suggests that neutral lipid synthesis can be optimized in two stages: first, by promoting growth and subsequently, by inducing lipid production.
\end{abstract}

Keywords: Fatty acids, Microalgae, Lipids, Photosynthesis, Photobioreactor.

Citation: Pérez-Pazos, J. V. \& Fernández-Izquierdo, P. (2011). Synthesis of neutral lipids in Chlorella sp. under different light and carbonate conditions. CT\&F - Ciencia, Tecnología y Futuro, 4 (4), 47-58.

*To whom correspondence should be addressed 


\section{RESUMEN}

L os lípidos son biomoléculas de gran interés científico y biotecnológico por sus amplias aplicaciones, las microalgas constituyen materia prima con potencial para síntesis de lípidos, particularmente Chlorella sp., es una de las más representativas debido al elevado contenido de lípidos y perfil idóneo para la obtención del biocombustible. La producción de lípidos en las microalgas se encuentra influenciada por varios factores físicos y químicos, la modificación de estos provoca una respuesta de estrés que se manifiesta por variaciones en la composición de lípidos sintetizados, que varía de una especie a otra. En esta investigación se evaluó el efecto de diferentes longitudes de onda de luz, fotoperiodos y suministro de carbonato de calcio $\left(\mathrm{CaCO}_{3}\right)$ en la síntesis de lípidos en la microalga Chlorella sp., para esto se cultivó la microalga en medio basal de Bold (Bold's Basal Medium, BBM) a $20^{\circ} \mathrm{C}$ y aireación constante, sometidas bajo longitudes de onda de luz azul $(470 \mathrm{~nm})$ y roja $(700 \mathrm{~nm})$, concentraciones $\mathrm{CaCO}_{3}$ de $0,5 \mathrm{~g} \cdot \mathrm{L}^{-1}$ y 1,5 $\mathrm{g} \cdot \mathrm{L}^{-1} \mathrm{y}$ fotoperiodos con fases de 6 horas luz y 18 horas oscuridad (6:18) y 18 horas luz y 6 horas oscuridad (18:6). Los resultados obtenidos indican que microalgas bajo luz roja, concentración de 0,5 g. L. $^{-1}$ de $\mathrm{CaCO}_{3}$ y fotoperiodo 6:18 presentaron mayor tasa de crecimiento, por otra parte, la producción de lípidos es mayor bajo luz azul, 1,5 g.:-1 de $\mathrm{CaCO}_{3}$ y fotoperiodo 18:6. Los resultados de los cromatrogramasmuestranácidos grasos como oleico, linoleico y palmitoleicode gran importancia en la industria del biodiesel. Estos resultados sugieren que es posible optimizar la síntesis de lípidos neutros en dos fases, primero promoviendo el crecimiento y posteriormente induciendo la producción de lípidos.

Palabras claves: Ácidos grasos, Microalgas, Lípidos, Fotosíntesis, Fotobiorreactor.

\section{RESUMO}

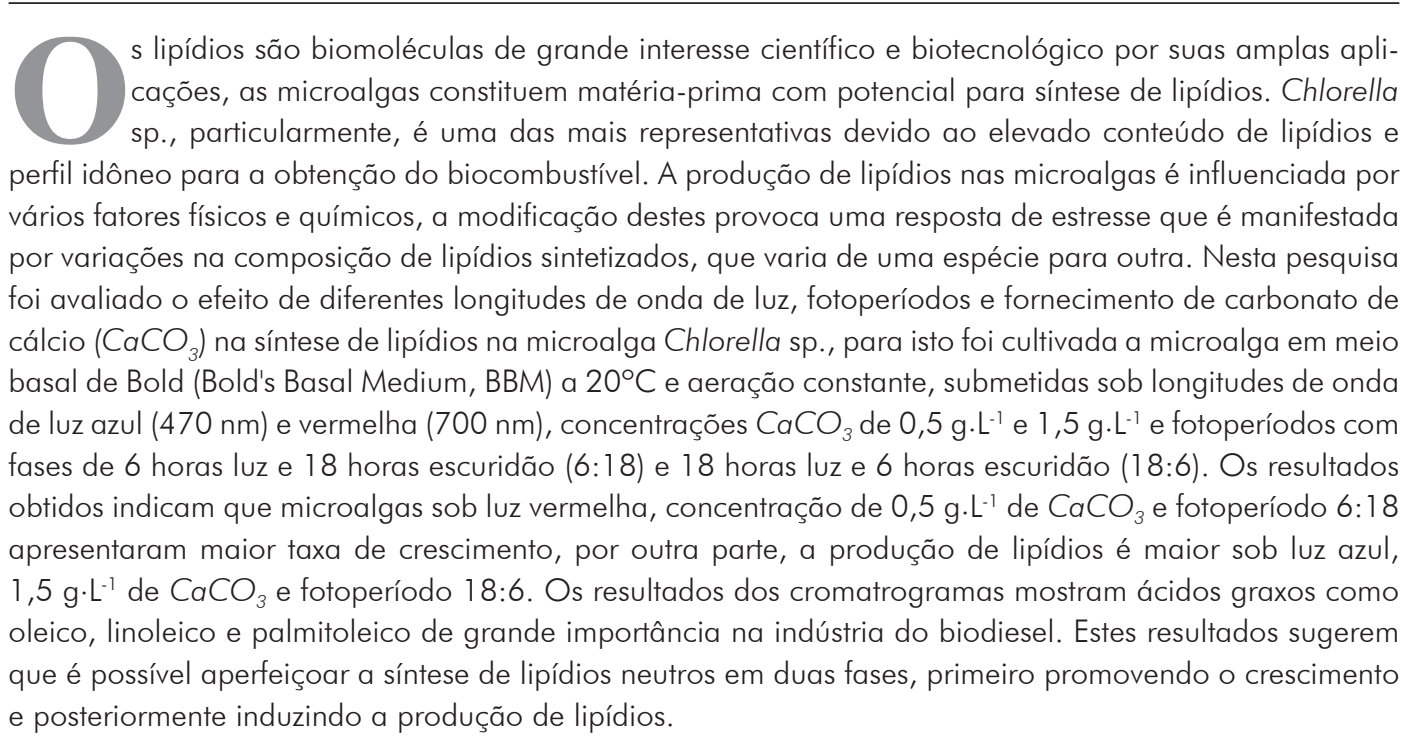

Palavras-chaves: Ácidos graxos, Microalgas, Lipídios, Fotossíntese, Fotobiorretor. 


\section{INTRODUCTION}

Lipids are a group of biomolecules that biologically have two important functions: serving as an energy source and as building blocks of the membranes in organisms (Segré, Ben-Eli, Deamer, \& Lancet, 2001). However, they have now taken on great biotechnological interest, because they play a major role in products such as cosmetics, pharmaceuticals, fuels, among others (Rutz \& Janssen, 2007). The lipids of a plant origin contain fatty acids and triglycerides, which are susceptible to esterification for use as a source of energy (Fahy et al., 2005; Villanueva, 2005; Hernandez \& Quintana, 2010). Up until now, in order to produce lipids from vascular plant species, extensive areas of land are used to grow the plants. In many cases this system of production leads to deterioration in soil quality and pollution of ecosystems with by-products from the extraction of lipids (Dismukes, Carrieri, Bennette, Ananyev \& Posewitz, 2008). Similarly, this type of agriculture has contributed to the deforestation of natural ecosystems and the substitution of crops for human consumption (Escudero, Cid \& Escudero, 2009). In order to minimize these disadvantages, the utilization of microalgae can be an efficient alternative for producing lipids (Xua, Miaoa \& Wu, 2006; Trösch \& Trick, 2008; Barajas et al., 2009; Hirth, 2009; Trösch, Mertsching \& Hirth, 2009).

Microalgae synthesize intracellular lipids in the form of neutral lipids (NLs), glycolipids (GLs) and phospholipids (PLS). These substances have a variable composition and concentration, reflecting the nature of the organism, the influence of culture conditions and the physiological state there of (Tokusoglu \& Ünal, 2003). The NLs are used as raw material for the production of biodiesel and they consist mainly of wax esters (WEs), triacylglycerols (TAGs), diacylglycerols and monoacylglycerols, (Borowitzka, 1995; Chen, Jiang \& Chen, 2007; Wältermann \& Steinbüchel, 2007). Due to this characteristic, this type of micro-organisms are a potential source of lipid synthesis for biofuel (Lee, Whitledge \& Kang, 2008; Jacob-Lopes, Gimenes-Scoparo, Ferreira-Lacerda \& Teixeira-Franco, 2009; Yoo, Jun, Lee, Ahn \& Oh, 2010).

The output of neutral lipid synthesis in microalgae is based on the variation of farming conditions, such as nutrient type and concentration (Yingying \& Changhai, 2009; Yeesang \& Cheirsilp, 2011), $\mathrm{CO}_{2}$ availability
(Mendes, Nobre, Cardoso, Pereira \& Palavra, 2003) temperature (Zepka, Jacob-Lopes \& Queiroz, 2007; Converti, Casazza, Ortiz, Perego \& Del Borghi, 2009), light type and intensity, photoperiod (Lee et al., 2008; Rosenberg, Oyler, Wilkinson \& Betenbaugh, 2008; Jacob-Lopes et al., 2009), among others. Light and carbon dioxide are essential factors that affect the physiological response in microalgae, because as phototrophic organisms, they use light photons as a source of energy and absorb carbon dioxide to synthesize organic compounds (Moheimani, 2005; Schulze, Beck \& Müller-Hohenstein, 2005; Lee et al., 2008). Therefore, variations in light intensity and carbon dioxide supply cause variations in the synthesis of neutral lipids (De Castro-Araújo \& Tavano-García, 2005; Rodríguez, Canales \& Borrás-Hidalgo, 2005; Sharkey, 2005; Bertoldi, Sant-Anna, Da-Costa \& Barcelos, 2006; Sharma, Kumar-Singh, Panda, Mallick, 2006; Chen et al., 2007)

It has been established that when the microalgae are grown with low light intensity, they assimilate carbon preferentially in the direction of the synthesis of amino acids and other essential cell components. However, under conditions of saturated light, they form sugars, lipids and starch through the pentose pathway, which involves phosphate reduction (Hoff \& Snell, 2004; Jacob-Lopes et al., 2009; Zak, et al., 2001). Furthermore, carbon is also a factor that determines lipid accumulation. Continuous carbon assimilation at a high concentration promotes the synthesis of fatty acids under this condition, and at a high light intensity, the lipids become a protective factor of the body against photo-oxidative stress (Grossman \& Takahashi, 2001; Hu et al., 2008; Rosenberg et al., 2008; Meng et al., 2009; Rodolfi et al., 2009).

Knowledge of the micro-organism's metabolism and control of environmental variables helps establish systems focused on obtaining micro-algae biomass with a high lipid content (Derner, Ohse, Villela, Matos-de Carvalho \& Fett, 2006; Chisti, 2007; Eriksen, 2008; Marinho, et al., 2009; Yingying \& Changai, 2009; Rogenski, 2010; Souza, 2010). However, the effect of each of the factors varies from one species to another. Therefore, in order to develop a technological strategy for biomass production and lipid synthesis, the effect of environmental factors in the micro-organism under study has to be assessed. Therefore, the effect of light and the $\mathrm{CO}_{2}$ supply in the growth and synthesis of the wild microalga Chlorella sp. was evaluated. IBUN 0016. 


\section{EXPERIMENTAL DEVELOPMENT}

\section{Strain and Culture}

For this study, the wild microalgae Chlorella sp. was used. The microorganism LAUN0016 was grown in Bold's Basal Medium (BBM) (Derner et al., 2006), supplemented with 1200000 UI penicillin G sodium. The sample was incubated in a photobioreactor with cool white light at a temperature of $20^{\circ} \mathrm{C}$ and a photoperiod of 12 hours light and 12 hours darkness, until growth was observed.

\section{Effect of Light and $\mathrm{CO}_{2}$ On the Synthesis of Neutral Lipids}

The pilot phase was conducted in a serpentine photobioreactor with closed fermentation driven by motor pumps with a range of $1 \mathrm{~m}$, in order to provide the system with constant agitation, with different colored lamps of cold light, red or blue, installed in each of the fermenters.

The photoperiod was controlled by a timer. Calcium carbonate $\left(\mathrm{CaCO}_{3}\right)$ was used as a carbon source and system temperature was $20^{\circ} \mathrm{C}$. A $2^{3}$ factorial design with 3 repetitions was applied. The factors of light wavelength, $\mathrm{CaCO}_{3}$ concentration and photoperiod, with their respective levels of variation, are shown in Table 1.

The response variables to be measured are: microalgae growth and lipid production. Growth was measured in units of absorbance at $750 \mathrm{~nm}$ every 24 hours using a Jenway Genoa spectrophotometer.

Neutral lipids were extracted according to a method described by Yellore and Desai (1998) and Braunnegg et al. (2007) with certain modifications described by Fernández, Ortiz, Guerrero, Burbano \& España (2006). Neutral lipids are extracted by adding $1,5 \mathrm{~mL}$ of hy- pochlorite at $5 \%$. After that, they are placed in a water bath at $60^{\circ} \mathrm{C}$ for 2 hours, and washed with distilled water followed by the addition of cold methanol. After that, they are centrifuged at $33000 \mathrm{~g}$ for $20 \mathrm{~min}$, to obtain the pellets, which represent neutral lipids.

\section{CHARACTERIZATION OF NEUTRAL LIPIDS}

The neutral lipids were characterized by gas chromatography using a method of pre-column derivatization of samples with $\mathrm{MeOH} / \mathrm{HCl} 5 \%$. After that, in a separating funnel, the fatty acid methanol esters (FAMEs) are extracted with hexane and $1 \mathrm{~mL}$ of the sample is injected into the chromatograph (Christie 2003). The run conditions were $150^{\circ} \mathrm{C}$ for 4 minutes $@ 250^{\circ} \mathrm{C}$ for $5 \mathrm{~min}, 4^{\circ} \mathrm{C} /$ minute. The detector, FID, $280^{\circ} \mathrm{C}$, the DB-5 column ( $30 \mathrm{~m}, 0,25 \mu \mathrm{m}, 0,25 \mathrm{~mm})$ on a Shimadzu GC 17A computer (Chen et al., 2007)

The fatty acids were quantified based on Equation 1 .

$$
F A(\%)=\frac{A i}{\Sigma A} \times 100 \%
$$

Where $A i$ is the area of the peak corresponding to component $i$, and $\Sigma A$ is the sum of the areas of all the peaks.

\section{RESULTS}

The effects of the variables light wavelength, $\mathrm{CaCO}_{3}$ supply and photoperiod on growth, chlorophyll production and lipid synthesis in the microalgae Chlorella sp. were evaluated through factorial design $2^{3}$. Results are shown in Table 2.

Table 1. Description of the levels of each of the factors used in factorial design $2^{3}$.

\begin{tabular}{|c|c|c|c|}
\hline Level & Light Wavelength & $\begin{array}{c}\text { Concentration of } \mathrm{CaCO}_{3} \\
\left(\mathbf{g} \cdot \mathbf{L}^{-1}\right)\end{array}$ & $\begin{array}{c}\text { Photoperiod } \\
\text { (Hourslight: HoursDarkness) }\end{array}$ \\
\hline 1 & $700 \mathrm{~nm}$ & 1,5 & $18: 6$ \\
\hline-1 & $500 \mathrm{~nm}$ & 0,5 & $6: 18$ \\
\hline
\end{tabular}


Table 2. Results factorial design $2^{3}$.

\begin{tabular}{|c|c|c|c|c|c|}
\hline $\begin{array}{c}\text { Light } \\
\text { Wavelength }\end{array}$ & $\begin{array}{c}\text { Experiment } \\
\text { Concentration } \\
\text { of } \mathrm{CaCO}_{3} \\
\left(\mathbf{g} \cdot \mathbf{L}^{-1}\right)\end{array}$ & $\begin{array}{c}\text { Photoperiod } \\
\text { (Hourslight: } \\
\text { HoursDarkness) }\end{array}$ & $\begin{array}{c}\text { Growth } \\
(\boldsymbol{\mu})\end{array}$ & $\begin{array}{c}\text { Total Chlorophyll } \\
\left(\mathbf{g} \cdot \mathbf{L}^{-1}\right)\end{array}$ & $\begin{array}{c}\text { Lipids } \\
\left(\mathbf{g} \cdot \mathbf{L}^{-1}\right)\end{array}$ \\
\hline $500 \mathrm{~nm}$ & 0,5 & $6: 18$ & $0,0105+/-0,0003$ & $0,0057+/-0,0006$ & $0,2481+/-0,0799$ \\
\hline $700 \mathrm{~nm}$ & 0,5 & $6: 18$ & $0,1090+/-0,0014$ & $0,0317+/-0,0009$ & $0,2261+/-0,0700$ \\
\hline $500 \mathrm{~nm}$ & 1,5 & $6: 18$ & $0,0112+/-0,0003$ & $0,0129+/-0,0010$ & $0,5631+/-0,0438$ \\
\hline $700 \mathrm{~nm}$ & 1,5 & $6: 18$ & $0,0119+/-0,0001$ & $0,0115+/-0,0015$ & $0,4334+/-0,0106$ \\
\hline $500 \mathrm{~nm}$ & 0,5 & $18: 6$ & $0,0100+/-0,0004$ & $0,0024+/-0,0001$ & $0,1714+/-0,0092$ \\
\hline $700 \mathrm{~nm}$ & 0,5 & $18: 6$ & $0,0102+/-0,0001$ & $0,0103+/-0,0005$ & $0,1540+/-0,0042$ \\
\hline $500 \mathrm{~nm}$ & 1,5 & $18: 6$ & $0,0112+/-0,0003$ & $0,0066+/-0,0008$ & $0,7783+/-0,0219$ \\
\hline $700 \mathrm{~nm}$ & 1,5 & $18: 6$ & $0,0135+/-0,0001$ & $0,0443+/-0,0027$ & $0,6539+/-0,0170$ \\
\hline
\end{tabular}

\section{Growth of the microalgae Chlorella sp.}

For the growth response variable, the analysis of the results of the experimental design indicates that all interactions of the first order are significant ( $\mathrm{p}$-value $<0,05$ ), with a reliability of $95 \%$. $\mathrm{CaCO}_{3}$ - photoperiod (p-value $=0,0085$ ) showed positive interaction. On the other hand, light - photoperiod ( $\mathrm{p}$-value $=0,0107)$ and Light - $\mathrm{CaCO}_{3}$ (p-value $=0,0113$ ) interactions are negative.

Growth in the microalgae Chlorella sp., under laboratory conditions is influenced by the interaction of all the variables. Figure 1a illustrates that the interaction of the factors $\mathrm{CaCO}_{3}$ - Photoperiod favors the growth of the microalgae when $\mathrm{CaCO}_{3}$ concentration is $0,5 \mathrm{~g} \cdot \mathrm{L}^{-1}$ and a 6:18 photoperiod. On the other hand, growth decreases significantly when calcium carbonate is found at a concentration of $1,5 \mathrm{~g} \cdot \mathrm{L}^{-1}$, regardless of the photoperiod. The interaction of the variables light and photoperiod favors the growth of micro-algae when the light presents a wavelength of $700 \mathrm{~nm}$ and a 6:18. On the other hand, when light is at a wavelength of 500 nm under any photoperiod, it reduces the growthof the microalga Chlorella sp., Figure 1b, while with a wavelength of $700 \mathrm{~nm}$ and a $\mathrm{CaCO}_{3}$ concentration of 0,5 $\mathrm{g} \cdot \mathrm{L}^{-1}$, Figure 1c, the growth of Chlorella sp.increases.

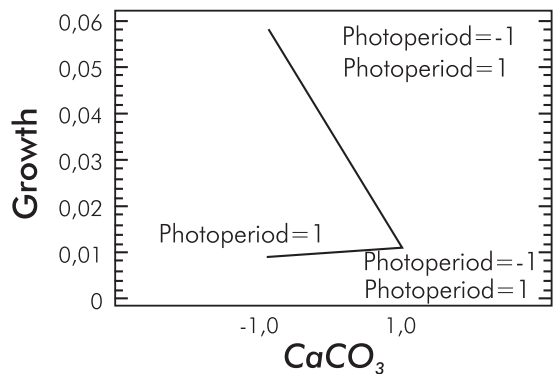

(a)

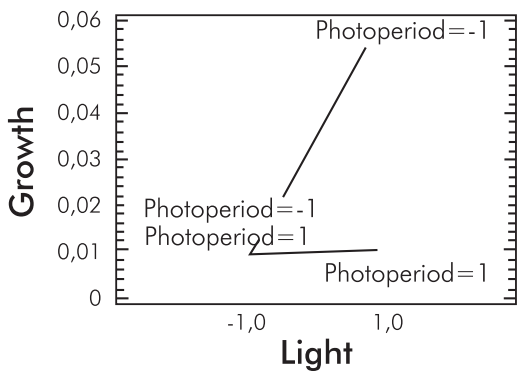

(b)

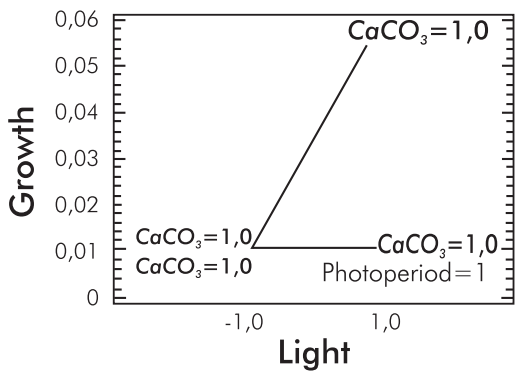

(c)

Figure 1. Interaction charts of the variables that affect growth.

(a) $\mathrm{CaCO}_{3}$ - Photoperiod; (b) Light - Photoperiod and (c) Light - $\mathrm{CaCO}_{3}$. 


\section{Synthesis of Neutral Lipids}

The Pareto Chart (Figure 2) shows that all the main effects and $\mathrm{CaCO}_{3}$ - Photoperiod interaction were significant. However, light has a negative effect on lipid synthesis when grown at a length of $700 \mathrm{~nm}$. On the other hand, carbonate-photoperiod interaction promotes the lipid synthesis when the carbonate concentration is $1,5 \mathrm{~g} \cdot \mathrm{L}^{-1}$ and when the photoperiod is 18:6 (Figure 3).

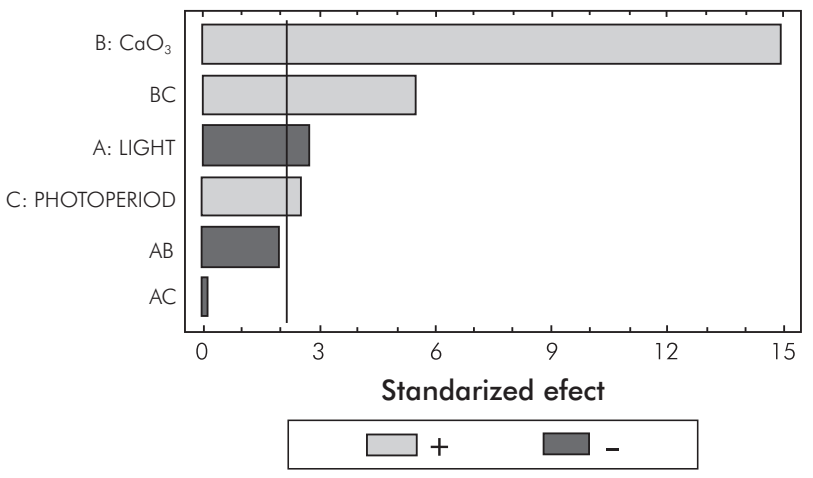

Figure 2. Standardized paretochart for lipids.

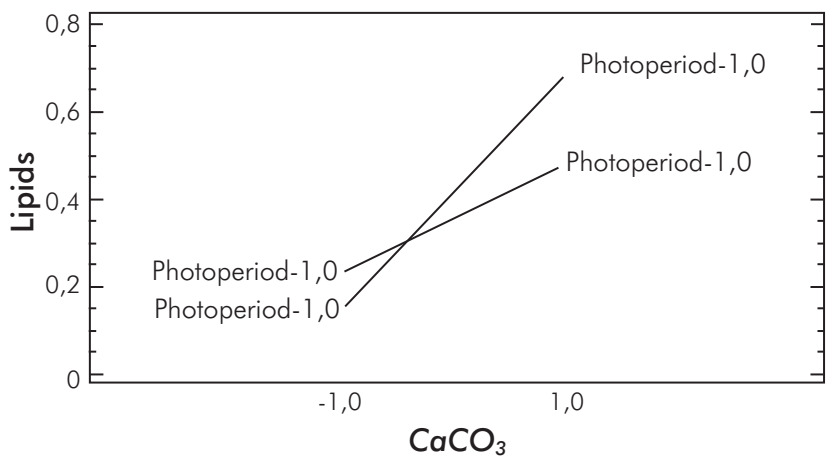

Figure 3. Chart Showing $\mathrm{CaCO}_{3}$ - Photoperiod interaction forlipids.

Characterization of the fatty acids synthesized by Chlorella sp., by gas chromatography.

The analysis of the lipid profile of the sample of Chlorella sp. by gas chromatography, under the best conditions of lipid synthesis with blue light; $\mathrm{CaCO}_{3}$ concentration of $1,5 \mathrm{~g} \cdot \mathrm{L}^{-1}$ and an $18: 6$, reported 10 compounds, three of which were identified: linoleic fatty acid, with a percen-tage of $6,45 \%$, palmitoleic fatty acid with a percentage of $4,01 \%$ and oleic fatty acid with a percentage of 2,75\% (Figure 4).

For the sample of Chlorella sp., under the best conditions of lipid synthesis with red light, a $\mathrm{CaCO}_{3}$ concentra- tion of $1,5 \mathrm{~g} \cdot \mathrm{L}^{-1}$ and an 18:6 photoperiod, 18 compounds were reported, one of which was identified, corresponding to linoleic fatty acid (Figure 5).

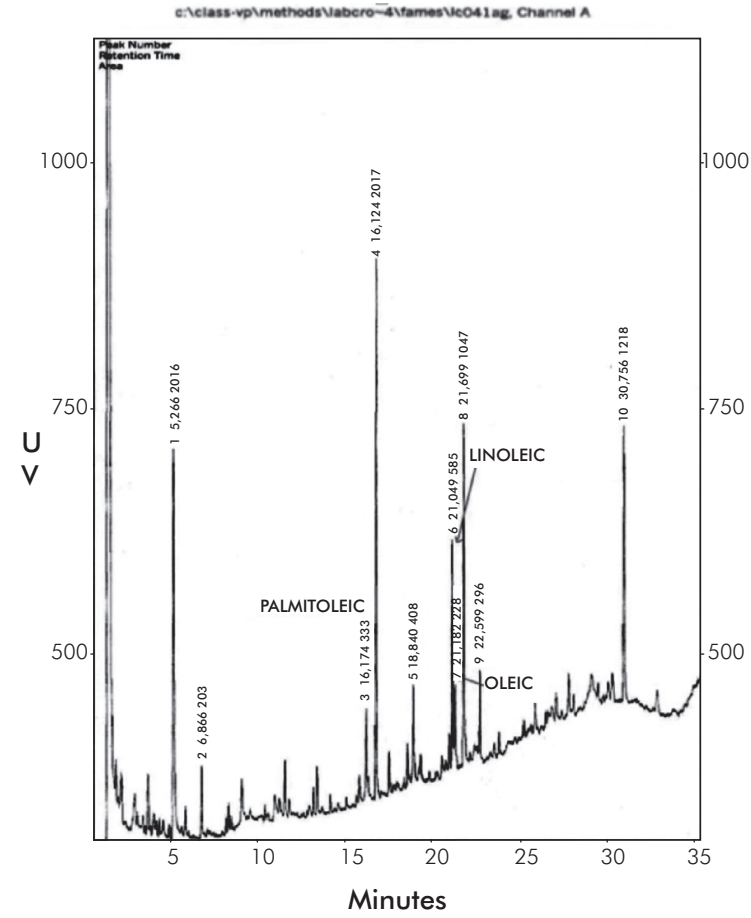

Figure 4. Analysis by gas chromatography of lipids produced by Chlorella sp. (Blue Light; $\mathrm{CaCO}_{3} 1,5 \mathrm{~g} \cdot \mathrm{L}^{-1} ; \mathrm{FP}$ 18:6).

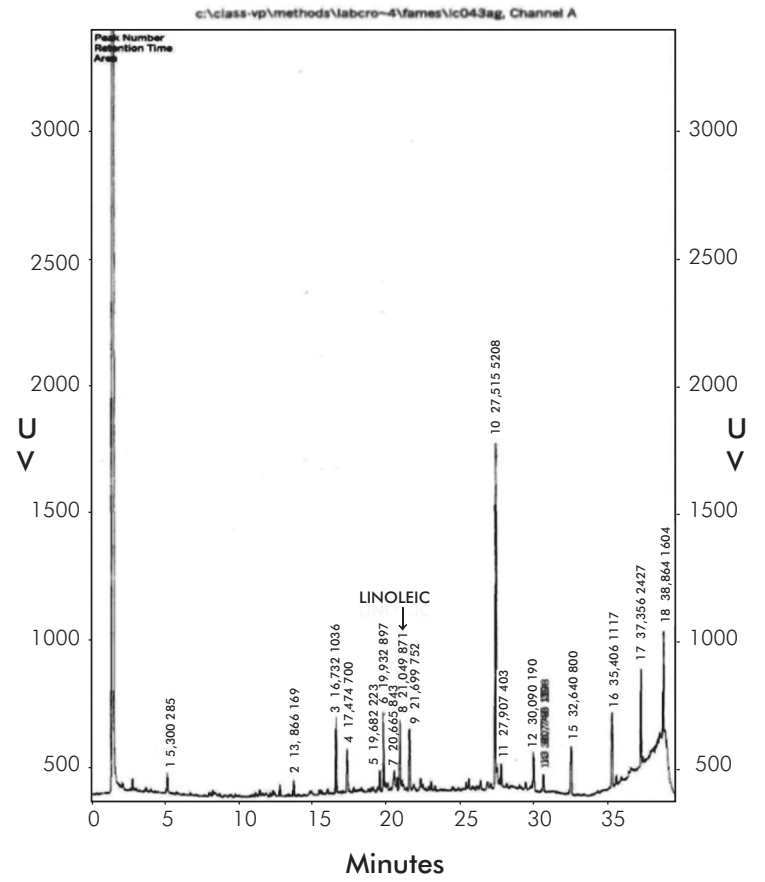

Figure 5 . Analysis by gas chromatography of lipids produced by Chlorella sp. (Red Light; $\mathrm{CaCO}_{3}$ 1,5 g.L-1; FP 18:6). 


\section{DISCUSSION}

All the factors and their interactions have significant effects on lipid synthesis as well as on microbial growth. In order to promote the growth, the most appropriate conditions are a wavelength of $700 \mathrm{~nm}$, a calcium carbonate concentration of $0,5 \mathrm{~g} \cdot \mathrm{L}^{-1}$ and a $6: 18$ photoperiod. Red light provides a higher level of excitement in the chlorophyll electrons, which causes a significant increase in the effectiveness of these pigments. The electrons produce water hydrolysis, which leads to the synthesis of ATP that is used for the synthesis of biomolecules that promote the growth of micro-algae (Rosemond, Mulholland \& Brawley, 2000; Piippo et al., 2006). With the excited chlorophylls and exposure to light, after 6 hours, there is enough energy and reduction power to sequester carbon and synthesize compound organisms through the Calvin cycle performed during the dark phase of photosynthesis, which in this case is 18 hours, so there is more time for the synthesis of organic compounds other than lipids. This behavior is probably due to the activation of the phytochrome by the red light that regulates the expression of some nuclear genes that produce chloroplastic proteins related to photosynthesis (Hill, 1996; Neff, Fankhauser \& Chory, 2000; Rosemond, et al., 2000; Piippo, et al., 2006). On the other hand, growingthe microalga Chlorella sp., LAUN0016, under the blue light, probably affects the expression of genes in the cell nucleus associated with lipid synthesis.

This study established that microalgae growth is favored at a calcium concentration of $0,5 \mathrm{~g} \cdot \mathrm{L}^{-1}$ because under these conditions, the carbonate is solubilized and is available to meet the carbon demand required for cell growth (Medadro \& Flexas, 2003; Massol-Deyá, Muñiz, Colón, Graulau \& Tang, 2005). But when the carbonate concentration is high, the solubility constant is exceeded and tends to precipitate; therefore there is not enough carbon available for microbial growth.

This study showed that for lipid synthesis, the best conditions are a wavelength of $500 \mathrm{~nm}$ corresponding to blue light, a calcium carbonate concentration of $1,5 \mathrm{~g} \cdot \mathrm{L}^{-1}$ and an 18:6 photoperiod.

The high lipid content seems to be an initial response to the exposure of microalgae in blue light, which has high energy content (Sánchez-Saavedra \& Voltolina, 2002;
Gupta \& Agrawal, 2006). Other studies have shown that the energy from blue light is captured by the pterin and transferred to the flavin, which probably intercedes in cryptochrome phosphorylation. This can cause a chain of signal transduction, which can affect the regulation of genes in the cell nucleus (Neff et al., 2000).

In this paper, the largest concentration of lipids with Chlorella sp. was obtained when using an 18:6 photoperiod. This condition can be considered a stress factor because, in the tropics, the organisms have photoperiods of $12: 12$. It can be assumed that microalgae exposed to 18 hours of light have an imbalance in oxide-reduction potential with accumulation of reduction power, which has to transfer the hydrogen ions to the reserve organic compounds such as the lipids to restore balance. This condition of stress is accentuated when the calcium carbonate concentration is $1,5 \mathrm{~g} \cdot \mathrm{L}^{-1}$ because at high concentrations, the carbonate is not available since it exceeds the solubility constant (Medadro \& Flexas, 2003; Massol-Deyá et al., 2005). However, there are some molecules available that can be assimilated pre-ferentially for lipid synthesis.

Altogether, these conditions can be considered a stress factor for Chlorella sp., which favors lipid synthesis. This state is characterized by the modification of the basic physiological functions causing the activation of defensive or response mechanisms that lead to the adjustment of cell metabolism to the new conditions (Piippo, et al., 2006; Tadeo, 2003). The microalgae grown photoautotrophically under conditions of severe stress assimilate carbon preferentially in the direction of the synthesis of amino acids and other special cell components, such as neutral lipids (Zak et al., 2001), since they require the increase in lipid composition, which is a determining factor in the restoration of photosynthetic machinery (Mendes \& Wagener; 2001; Medadro \& Flexas, 2003). It is important to point out that variation in Chlorella sp. growth conditions also affected lipid composition and concentration, but this type of response varies from one species to another (Sanchez, Martinez \& Espinola, 2006).

\section{CONCLUSIONS}

- These findings underscore the importance of controlling light wavelength, carbonate concentration and photoperiod because these factors affect both growth 
and the synthesis of neutral lipids in the microalgae Chlorella sp.

- The levels of light wavelength, carbonate concentrations and photoperiod that favor growth inhibit lipid synthesis; in the same sense, the conditions that favor the synthesis of neutral lipids produce an inverse response in the growth of Chlorella sp.

- The lipid profile obtained under a light wavelength of $500 \mathrm{~nm}$ is different from that obtained whenthe microalgae Chlorella sp., is grown at $700 \mathrm{~nm}$. This suggests that the type and concentration of lipids synthesized by manipulating light wavelength can be controlled.

\section{ACKNOWLEDGMENTS}

We would like to thank the Research System of the Vice Rectory for Research, Graduate Programs and International Relations (VIPRI) at Universidad de Nariño for funding the research, and the Microbial Biotechnology Group at the same institution for their collaboration in conducting it. Also, Luis Carlos Montenegro Ruiz, from the In Vitro Microalgae Research Group at Universidad Nacional de Colombia, for donatingthe microalgae Chlorella sp.

\section{REFERENCES}

Barajas, A., Garzón, L., González, A, Guzmán, A., Kafarov, V., Moreno, N., Nuñez, M., Plata, M. \& Velasquez, G. (2009). Bioprospección de microalgas colombianas para la producción de biodiesel. IV Congreso Internacional de Ciencia y Tecnología de los Biocombustibles y Seminario Internacional de Biocombustibles y Co-Productos a Partir de Microalgas. Bucaramanga, Colombia.

Bertoldi, F. C., Sant-Anna, E. S., Da-Costa, M. V. \& Barcelos, J. L. (2006). Lipids, fatty acids composition and carotenoids of Chlorella vulgaris cultivated in hydroponic wastewater. Grasas y Aceites, 57 (3), 270-274.
Borowitzka, M. A. (1995). Microalgae as sources of pharmaceuticals and other biologically active compounds. $J$. Appl. Phycol., 7 (1), 3-15.

Braunegg, G., Atlic, A., Bona, R., Koller, M., Hesse, P. \& Kutschera, C. (2007). Biotechnological polyester production from renewable resources. Fifth Croatian Scientific Conference on Biotechnology with International Central-European Participation: Biotechnology, Energy, Chemicals and Renewable Raw Materials. StubickeToplice, Croatia.

Converti, A., Casazza, A. A., Ortiz, E.Y., Perego, P. \& Del Borghi, M. (2009). Effect of temperature and nitrogen concentration on the growth and lipid content of Nannochloropsisoculata and Chlorella vulgaris for biodiesel production. Chem. Eng. Process., 48 (6), 1146-1151.

Chen, G. Q., Jiang, Y. \& Chen, F. (2007). Fatty acid and lipid class composition of eicosapentaenoic acid producing microalga Nitzschialaevis. Food Chemistry, 104 (4), 1580-1585.

Chisti, Y. (2007). Biodiesel from Microalgae. Biotechnol. Adv. 25: 294-306.

Christie, W. (2003). Lipid Analysis. Isolation, separation, identification and structural analysis of lipid. $3^{\mathrm{a}}$ ed. Bridgwater, Inglaterra: The Oily Press.

De Castro-Araújo, S. \& Tavano-García, V. M. (2005). Growth and biochemicals composition so the diatom Chaetoceroswighamii bright well under different temperature, salinity and carbon dioxide levels. Proteins, carbohydrates and lipids. Aquaculture, 246 (1-4), 405-412.

Derner, R. B., Ohse, S., Villela, M., Matos de Carvalho, S. \& Fett, R. (2006). Microalgas, produtos e aplicacóes. Ciencia Rural, Santa María, 36 (6), 1959-1967.

Dismukes, G. C., Carrieri, D., Bennette, N., Ananyev, G. M. \& Posewitz, M. C. (2008). Aquatic phototrophs: efficient alternatives to land-based crops for biofuels. Curr. Opin. in Biotechnol., 19 (3), 235-240.

Eriksen, N. T. (2008). The technology of microalgal culturing. Biotechnol. Lett., 30 (9), 1525-1536.

Escudero, M., Cid, C. \& Escudero, R. (2009). La Controversia De los Agrocombustibles, Una Propuesta Didáctica para Las Ciencias para el Mundo Contemporáneo. Revista 
Eureka Sobre Enseñanza y Divulgación de las Ciencias, $6(1), 131-139$.

Fahy, E., Subramaniam, S., Brown, A., Glass, C. K., Merrill, A. H., Murphy, R. C., Raetz, C. R. H., Russell, D. W., Seyama, Y., Shaw, W., Shimizu, T., Spener, F., Van M. G., Van Nieuwenhze, M. S., White, S. H., Witztumand, J. L. \& Dennis, E. A. (2005). A comprehensive classificationsystem for lipids. J. Lipid Res., 46 (5), 839-862

Fernández, P., Ortiz, F., Guerrero, M., Burbano, O. \& España, J. (2006). Influencia de fuentes de carbono y nitrógeno en la síntesis de copolímero Poli-(hidroxibutirato-co-hidroxivalerato) de una cepa Silvestre de Bacillusmycoides. Rev. Universidad y Salud, 1 (7), 34-42.

Grossman, A. \& Takahashi, H. (2001).Macronutrient utilization by photosynthetic eukaryotes and the fabric of interactions. Annu. Rev. Plant Physiol. Plant Mol. Biol., 52 (1), 163-210.

Gupta, S. \& Agrawal, S. C. (2006). Survival of blue - green and green algae under stress conditions. Folia. Microbiol. 51 (2), 121-128.

Hernández, L. \& Quintana, M. (2010). Biotecnología y Microalgas. Las investigaciones biotecnológicas y el uso de la energía solar como fuente energética en la fase de fermentación reportan beneficio social. Centro de Investigaciones de Energía Solar (CIES) Copyright Cubasolar 2000-2011. Consultado 02 Julio de 2011. Disponible en $<$ http://www.cubasolar.cu/biblioteca/energia/Energia25/ HTML/articulo03.htm>.

Hill, W. (1996). Algal ecology: freshwater benthic ecosystems. Effects of light. 121-148 pp. USA: Academic Press.

Hirth, T. (2009).Microalgae-A. Sustainable Resource for Valuable Compounds and Energy. FraunhoferInstitute For Interfaciel Engineering and Biotechnology IGB. Consultado 28 de Mayo 2011. Disponible en <http:// www.igb.fraunhofer.de/content/dam/igb/de/documents/ broschueren/Microalgae_a_sustainable_resource_for_ valuable_compounds_and_energy.pdf $>$

Hoff, F. H. \& Snell, T. W. (2004). Plankton culture manual. Sixth Edition. Florida: Florida aqua farms. Inc.

Hu, Q., Sommerfeld, M., Jarvis, E., Ghirardi, M., Posewitz, M., Seibert, M. \& Darzins, A. (2008). Microalgaltriacylglycerols as feedstock for biofuel production: perspectives and advances. Plant J., 54 (4), 621-639.
Jacob-Lopes, E., Gimenes-Scoparo, C. H., Ferreira-Lacerda, L. M. \& Teixeira-Franco, T. (2009). Effect of light cycles (night/day) on $\mathrm{CO}_{2}$ fixation and biomass production by microalgae in photobioreactors Original Research Article. Chem. Eng. and Process., 48 (1), 306-310.

Lee, S. H.,Whitledge, T. E. \& Kang, S. H. (2008). Carbon Uptake Rates of Sea Ice Algae and Phytoplankton under Different Light Intensities in a Landfast Sea Ice Zone, Barrow, Alaska. Arctic, 61 (3), 81-291.

Marinho, Y., Dos Santos, A., Dos Santos, L., Vasconcelos, R., Kalazans, N., Do Nascimento, R., Dantas, D., Galvez, A. (2009). Avaliação do crescimento da Chlorella vulgaris em diferentes $\mathrm{pH}$ Objetivando Sua Inserção Na Matéria prima Do Biodiesel. Jornada de Ensino, Pesquisa e Extensão - JEPEX. Universidade Federal Rural de Pernambuco..

Massol-Deyá, A., Muñiz, R., Colón, M., Graulau, J. \& Tang, N. S. (2005). Microbial Community Structure of Pentachlorophenol Contaminated Soils as Determined by Carbon Utilization Patterns. Caribb J. Sci., 41 (1), 138-146.

Medadro, H. \& Flexas, J. (2003). Fundamentos de fisiologia vegetal. Fijación del dióxido de carbono y biosintesis de fotoasimilados. Primera Edición. España: McGraw-Hill. Interamericana.

Mendes, L. B. \& Wagener, K. (2001). High Spirullina productivity under intensive light. Arch. hydrobiol., 140 (13), 151-160.

Mendes, R. L., Nobre, B. P., Cardoso, M. T., Pereira, A. P. \& Palavra, A. F. (2003). Supercritical carbon dioxide extraction of compounds with pharmaceutical importance from microalgae. Inorganica Chimica Acta, 356 (1), 328-334.

Meng, X., Yang, J., Xu, X., Zang, L., Nie, Q. \& Xian, M. (2009). Biodiesel production from oleaginous microorganisms. Renew. Energ., 34 (1), 1-5.

Moheimani, N. R. (2005). The cultura of Coccolithophorid algae for carbón dioxide bioremediation. Thesis for obtained the degree of Doctor of Philosophy of Murdoch University. Perth, Australia, 266pp.

Neff, M. M., Fankhauser, C. \& Chory, J. (2000). Light: an indicator of time and place. Genes and Development., 14 (3), 257-271. 
Piippo, M., Allahverdiyeva, Y., Paakkarinen, V., Suoranta, U.M., Battchikova, N. \& Aro, E. M. (2006). Chloroplastmediated regulation of nuclear genes in Arabidopsis thaliana in the absence of light stress. Physiol. Genomics, 25 (1), 142-152.

Rodolfi, L., Zittelli, G. C., Bassi, N., Padovani, G., Biondi, N., Bonini, G. \& Tredici, M. R. (2009). Microalgae for oil: strain selection, induction of lipid synthesis and outdoor mass cultivation in a low-cost photobioreactor. Biotechnol. Bioeng., 102 (1), 100-112.

Rodríguez, M., Canales, E. \& Borrás-Hidalgo, O. (2005). Molecular aspects of abiotic stress in plants. Biotecnología Aplicada, 22 (1), 1-10.

Rogenski, D. M. (2010). Otimização Do Meio De Cultura Para A Microalga PhaeodactylumTricornutum Para Produção De Lipídios. Tesis de Maestria. Facultad de Ciências Biológica.Universidade Federal do Paraná. Curitiba, Brasil, 114pp.

Rosemond, A. D., Mulholland, P. J. \& Brawley, S. H. (2000). Seasonally shifting limitation of stream periphyton: response of algal populations and assemblage biomass and productivity to variation in light, nutrients, and herbivores. Can. J. Fish. Aquat. Sci., 57 (1), 66-75.

Rosenberg, J. N., Oyler, G. A., Wilkinson, L. \& Betenbaugh, M. J. (2008). A green light for engineered algae: redirecting metabolism to fuel a biotechnology revolution. Curr. Opin. Biotechnol., 19 (5), 430-436.

Rutz, D. \& Janssen, R. (2007). BioFuel Technology Handbook. Germany: WIP Renewable Energies.

Sánchez, S; Martínez, E. \& Espinola, F. (2006). Biomass production and biochemical variability of the marine microalgae Isochrysisgalbana in relation to culture medium. J. Biochem. Eng., 6 (1), 13-18.

Sánchez-Saavedra, M. P. \& Voltolina, D. (2002). Effect of photon fluence rates of white and blue-green light on growth efficiency and pigment content of three diatoms species in batch cultures. Ciencias Marinas, 28 (3), 273279.

Schulze, E. D., Beck, E. \& Müller-Hohenstein, K. (2005). Environment as Stress Factor: Stress Physiology of Plants. Plant. Ecol., 702 (9), 506.

Segré, D., Ben-Eli, D., Deamer, D. W. \& Lancet, D. (2001).The Lipid World. Origins Life Evol. Biosphere., 31 (1-2), 119-145.
Sharkey, T. D. (2005). Effects of moderate heat stress on photosynthesis: importance of thylakoid reactions, rubisco deactivation, reactive oxygen species, and thermotolerance provided by isoprene. Plant Cell and Environ., 28 (3), 269-277.

Sharma L., Kumar-Singh A., Panda B. \& Mallick N. (2006). Process optimization for poly-b-hydroxybutyrate production in a nitrogen fixing cyanobacterium, Nostocmuscorum using response surface methodology. Bioresource Technol., 98 (5), 987-993.

Souza, S. G. (2010). Essential fatty acids: importance of fish oils and aquaculture. Braz. J. Food Technol., 13 (3), 189-196.

Tadeo, F. R. (2003). Fundamentos de fisiología vegetal. Fisiología de las plantas y el estres. Primera Edición. Spain: McGraw-Hill. Interamericana.

Tokusoglu, Ö. \& Ünal, M. (2003). Biomass nutrients profiles of three microalgae: Spirulinaplatensis, Chlorella vulgaris, and Isochrisis Galbana, Food Chem. Toxicol., 68 (4), 1144-1148.

Trösch, W. \& Trick, I. (2008). Sustainable bioprocess engineering for industry, urban infrastructure, and the environment. In Annual Report 2007-2008. Fraunhofer Institute ForInterfaciel Engineering and Biotechnology IGB.

Trösch, W., Mertsching, H. \& Hirth, T. (2009). Material and Energetic Use of Microalgas Lipids. In Annual Report 2008-2009. Fraunhofer Institute for Interfaciel Engineering and Biotechnology IGB.

Villanueva, L. (2005). Ecophysiological and molecular characterization of estuarine microbial mats. Tesis doctoral. Facultad de Biología. Universidad de Barcelona. Barcelona, España. 155pp.

Wältermann, M. \& Steinbüchel, A. (2007). Neutral Lipid Bodies in Prokaryotes: Recent Insights into Structure, Formation, and Relationship to Eukaryotic Lipid Depots. J. Bacteriol., 187 (11), 3607-3619.

Xua, H., Miaoa, X. \& Wu, Q. (2006). High quality biodiesel production from a microalga Chlorella protothecoides by heterotrophic growth in fermenters. J. Biotechnol., $126(4), 1-15$.

Yeesang, C. \& Cheirsilp, B. (2011). Effect of nitrogen, salt, and iron content in the growth medium and light intensity 
on lipid production by microalgae isolated from freshwater sources in Thailand. Bioresource Technol., 102 (3), 3034-3040.

Yellore, V. \& Desai, A. (1998). Production of poly-b-hydroxy butyrate from lactose and whey by Methylobacterium sp. ZP24. Letters in Applied Microbiology, 26 (6), 391-394.

Yingying, S. \& Changhai, W. (2009). The Optimal Growth Conditions for the Biomass Production of Isochrysisgalbana and the Effects That Phosphorus, $\mathrm{Zn}_{2}+, \mathrm{CO}_{2}$, and Light Intensity Have on the Biochemical Composition of Isochrysisgalbana and the Activity of Extracellular CA. Biotechnol. Bioprocess Eng., 14 (2), 225-231.

Yoo, C., Jun, S. Y., Lee, J. Y., Ahn, C. Y. \& Oh, H. M. (2010). Selection of microalgae for lipid production under high levels carbon dioxide. Original Research Article. Bioresource Technol., 101 (1), S71-S74.

Zak, E., Norling, B., Maintra, R., Huang, F., Andersson, B. \& Pakrasi, B. (2001). The initial steps of biogenesis of cyanobacterial photosystems occurs in plasma membranes. Plant Biol., 98 (23), 13443-13448.

Zepka, L. Q., Jacob-Lopes, E. \& Queiroz, M. I. (2007). Efecto del Procesamiento Térmico sobre el Perfil de Ácidos Grasos de la Microalga Aphanothece Microscopica Nägeli. Ciencia y Tecnologia Alimentaria, 5 (5), 368-371. 
